\title{
Estimation of gastric ghrelin-positive cells activity in hyperthyroid rats
}

\author{
Jacek Dadan1, Robert L. Zbucki ${ }^{1,2}$, Bogusław Sawicki³, Maria M. Winnicka ${ }^{2}$ \\ ${ }^{1} 1^{\text {st }}$ Department of General and Endocrinological Surgery, ${ }^{2}$ Department of General and Experimental \\ Pathology, ${ }^{3}$ Department of Histology and Embryology, Medical University of Białystok, Poland
}

\begin{abstract}
Ghrelin is a peptide of 28 amino acids that transmits appetite related signals from peripheral organs to the brain. The main source of ghrelin is stomach. The regulation of ghrelin secretion is still unknown. The finding that fasting and food intake, respectively increase and decrease the secretion of ghrelin suggests that this hormone may be a bridge connecting somatic growth with energy metabolism and appears to play an important role in the alteration of energy homeostasis and body weight in pathophisiological conditions. The purpose of this study was the evaluation of gastric ghrelin immunoreactivity and ghrelin plasma concentration in male Wistar rats with hyperthyroidism. Experimental model of hyperthyroidism was induced by intraperitoneal injection of levothyroxine at the dose of $80 \mu \mathrm{g} / \mathrm{kg}$ daily over 21 days. At the end of experiment the animals were anaesthetized, blood was taken from abdominal aorta to determinate plasma ghrelin concentration by RIA and then the animals underwent resection of distal part of stomach. Immunohistochemical study were performed using monoclonal specific antybodies against ghrelin. Hyperthyroidism was a reason of increase of gastric mucosal ghrelin - immunoreactivity, accompanied by a significant decreased of ghrelin plasma concentration. Those observations may indicate, that chronic administration of L-thyroxine cause the change of ghrelin plasma concentration in rats, probably via direct influence on gastric X/A-like cells, but this effect is not responsible for hyperphagia associated with hyperthyroidism.
\end{abstract}

Key words: hyperthyroidism, L-thyroxin, ghrelin, immunohistochemistry, rats

\section{Introduction}

The regulation of energy metabolism is one of the major points of homeostatic system, in which the brain acts as the central coordinator. The important role trying to synchronize response to fluctuations in energy balance play brain-gut axis, realized by autonomic nervous system and endocrine system. Many of peripheral factors (leptin, insulin, peptide YY, ghrelin) are involved in regulation of energy balance [1-3].

Ghrelin is a of 28 amino acids hormone that has been recently isolated from rat and human stomach [4]. This peptide is recognized as a main endogenous ligand for growth hormone secretagogue receptors (GHS-R) and it play important roles in growth hormone release and control of feeding behaviour $[4,5]$. The acyl group at serine-3 of ghrelin molecule is essential for binding and activing GHS-R. GHS-R1a is

Correspondence: J. Dadan, $1^{\text {st }}$ Department of General and Endocrinological Surgery, Medical University of Białystok, M. Skłodowskiej-Curie 24a, 15-276 Białystok, Poland; e-mail: jacdad@poczta.onet.pl highly expressed in the hypothalamus and pituitary gland, consistent with the actions of ghrelin on the anterior pituitary, as well as with its influence in the control of appetite, food intake and energy balance $[4,6]$. Moreover, GHS-R1a expression has also been reported in other areas of the central nervous system, that affect biological rhythms, mood, cognition memory and learning, such as the hippocampus, substantia nigra, ventral tegmental area, dorsal and medial raphe nuclei, Edinger-Westphal nucleus and pyriform cortex $[7,8]$. In addition, multiple peripheral organs, such as the stomach, intestine, pancreas, thyroid, gonads, adrenal, kidney, heart and vascular system as well as several endocrine tumors and cell lines have been found to express GHS-R1a $[8,9]$.

The stomach is the main source of circulating ghrelin level and this fact has been demonstrated by their decrease after gastrectomy [10]. Ghrelin expression has been detected in X/A-like cells that account for 20$25 \%$ of all endocrine cells in the mucosa $[4,6,11]$. Ghrelin has been also localized in many other tissues such as: pancreas, bowel, kidney, placenta, gonads, thyroid, adrenal, lung, pituitary, hypothalamus $[4,8,12]$ 
and in many neoplastic tissues such as gastric, intestinal carcinoid, thyroid and breast carcinomas $[9,13]$. The potential physiological role of ghrelin as an autocrine and paracrine factor in those tissues is still investigated. The endocrine function of ghrelin seems to be better known $[1,2]$.

Ghrelin is able to induce adipogenesis in rodents by stimulating appetite and food intake as well as by modulating energy balance with reduced fat utilization $[8,14,15]$. The orexigenic action of ghrelin and GHS is independent from GH-releasing activity and is mediated by a specific central network of neurones that is also modulated by leptin [15]. Ghrelin and leptin might be complementary players of one regulatory system that has developed to inform the central nervous system about the status of energy balance $[7,15,16]$. From the gastrointestinal tract, ghrelin could regulate food intake and energy homeostasis reaching GHS-R in the hypothalamus through the general circulation $[7,14]$. Moreover, ghrelin expression has also been demonstrated in a previously uncharacterized group of neurones adjacent to the third ventricle between the dorsal, ventral, paraventricular and arcuate hypothalamic nuclei $[2,3,14]$. Within the hypothalamus, ghrelin binds mostly on presynaptic terminals of neuropeptide Y (NPY) neurones; it stimulates the activity of arcuate NPY neurones and mimicks the effect of NPY in the paraventricular nucleus of the hypothalamus $[3,14,17,18]$. There is also evidence that acetylcholine mediates the ghrelin impact on appetite and energy balance [19].

The aim of this study was was the evaluation of gastric ghrelin immunoreactivity and ghrelin plasma concentration in male Wistar rats with hyperthyroidism.

\section{Material and methods}

Animals. The study was performed on twenty, male Wistar rats weighting approximately $90-100 \mathrm{~g}$ at the beginning of the experiment. All animals had free access to standard granulated diet and drinking water. The animals were housed in plastic cages at $22^{\circ} \mathrm{C}$ and constant humidity, with a 12/12-light/dark cycle, beginning at $7 \mathrm{am}$. The rats were randomly divided into 2 groups with 10 animals in each group: rats with hyperthyroidism and control rats treated with vehicle under the same experimental conditions. Experimental model of hyperthyroidism was induced by intraperitoneal injection of L-thyroxine (Sigma Chemical Co) at the dose of $80 \mu \mathrm{g} / \mathrm{kg}$ daily over 21 days.

At the end of experiment, the animals were anaesthetized with pentobarbital sodium $(50 \mathrm{mg} / \mathrm{kg}$ b.wt), their abdomen was opened by midline incision and the blood was taken from the abdominal aorta of each rat for measurement of TSH and ghrelin serum concentration by radioimmunoassay (RIA). Subsequently, all rats underwent resection of distal part of stomach. The tissues were fixed in Bouin's fluid and were prepared to immunohistochemical investigation.

Determination of TSH and ghrelin plasma concentration. The blood, taken from abdominal aorta of each rat, was collected into polypropylene tubes without anticoagulant and was incubated in room temperature until the clot was formed and then centrifuged $(2500 \times \mathrm{g}$ for $15 \mathrm{~min})$. The supernatant (serum) was removed and stored at $-20^{\circ} \mathrm{C}$ until a final analysis. Ghrelin and TSH level was determined by the double-antibody radioimmunoassay technique. The protocol for radioimmunoassay kit is accessible on the web site: www.phoenixpeptide.com.

The immunohistochemical study. The distal part of stomach of each animal was fixed in Bouin's fluid for one day at $4^{\circ} \mathrm{C}$. After thorough washing in $0.1 \mathrm{M}$ phosphate buffer $(\mathrm{pH}=7.4)$ at $4^{\circ} \mathrm{C}$, the tissue was routinely embedded in paraffin, and 5- $\mu \mathrm{m}$-thick sections were cut. For blocking of the endogenous peroxidase activity Peroxidase Blocking Reagent (Dako Poland) was used over 10 minutes. In these studies a specific antibody against ghrelin (Phoenix) was used. After washing with distilled water and $0.05 \mathrm{M}$ TRIS-HCl $\mathrm{pH}=7.4$, three times for 5 minutes, the sections were incubated with the antibody for 1 hour at room temperature and then, sections were washed three times in TRIS buffer. Subsequently, the EnVision method was applied, according to the protocol for identification of the immunocytochemical reaction [20]. The sections were counterstained with Mayer's haematoxylin. In the negative control, the specific antibody was omitted in the staining procedure. Positive control was done for specific tissue recommended by the producer. The histological preparations were subjected to analysis, using Olympus $\mathrm{B} \times 50$ microscope.

Image analysis. To quantify immunoreactivity of the examined marker, computerized image analysis was performed. Images were captured via video link to an Olympus BX50 microscope at 20 objective magnification, so the tissue fully occupied each field, and was scanned by the computer. Pictures were adjusted for optimal contrast, fixed at the same brightness levels, and saved in a buffering system. Staining was analyzed using Olympus Cell D image analysis computer system as described in details by Postek et al. [21]. The average optical density was analyzed for cells expressing ghrelin in both, experimental and control rats. The average optical density is the method measured values range from 0 to 255 where 0 means black and 255 white color.

Ethical issues. All procedures were performed in compliance with the European Communities Council Directive of 24 November 1986 (86/609/EEC) and were approved by the Local Ethics Committee in Białystok.

Statistics. All values were given as mean \pm SD. The Mann-Whitney test was used for testing the differences between both groups in the intensity of immunocytochemical reactions. The Student- $t$ test was used for the evaluation of the differences between groups in ghrelin plasma concentrations. The value $\mathrm{p}<0.05$ was considered to be significant.

\section{Results}

\section{Radioimmunoassay}

After 21 days of L-thyroxine treatment plasma TSH concentration was significantly $(\mathrm{p}<0.001)$ reduced (mean $0.52 \pm 0.14 \mu \mathrm{IU} / \mathrm{ml}$ ) as compared to the respective value in the control rats $(2.89 \pm 0.59 \mu \mathrm{IU} / \mathrm{ml})$ (Fig. 1). Initial food intake did not differ between two groups. After 1 week of treatment the food intake gradually increased compared to the control group. At the end of experiments body weights significantly decreased in rats with hyperthyroidism. The adminis- 


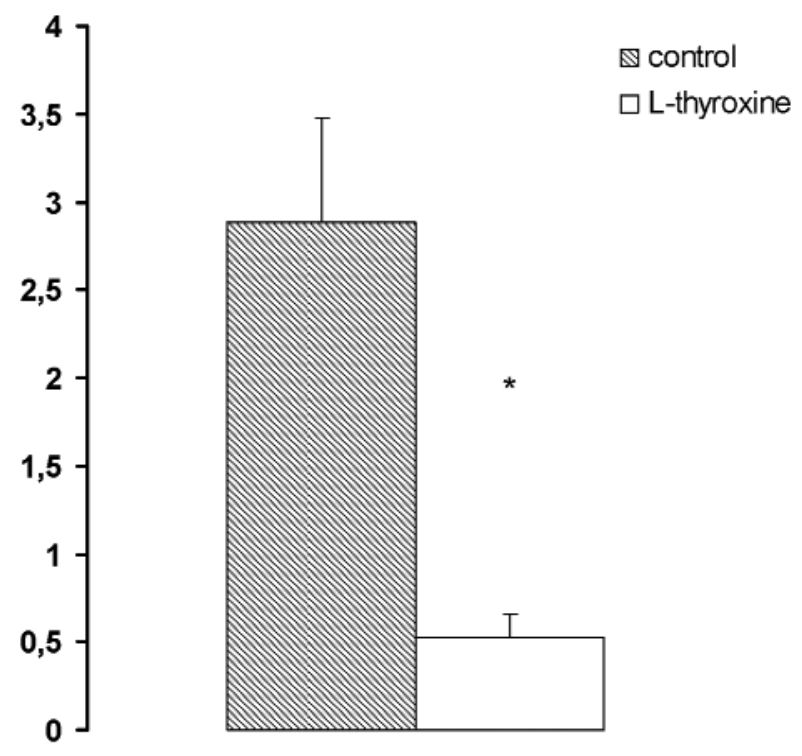

Fig. 1. The effect of L-thyroxine on plasma TSH concentration. Values are means \pm SD obtained from 10 rats. ${ }^{*} p<0.001$ vs control (Student's test).

tration of L-thyroxin over 21 days caused significantly decreased of plasma ghrelin concentration (mean $388.8 \pm 58.3 \mathrm{pg} / \mathrm{ml}$ ) in comparison to the control rats (mean $634.8 \pm 62.2 \mathrm{pg} / \mathrm{ml}$ ) (Fig. 2).

\section{Results of histological study}

Ghrelin immunoreactive (Ghr-IR) cells were distributed predominantly as single cells, locally in varying number in the deep zone of the gastric mucosa. Ghr-IR cells were most abundant in lower parts of gastric proper glands, while in the neck zone of the glands they were observed sporadically, both in the control (Fig. 4) and in the experimental groups of rats (Fig. 6). These cells were usually round or oval, sometimes spindle-shaped, seldom irregular with short processes. Their nuclei were usually large, round structures that occupy the central portions of cells. While in the X/A like cells of control rats GH-immunoreactivity appeared as a strong reaction (Fig. 4 and 5), after chronic treatment with L-thiyroxine (Fig. 6 and 7), GH-immunoreactivity in gastric mucosa was stronger. The average optical density of immunocytochemical reaction for ghrelin, evaluated by Olympus Soft program, was significantly decreased in L-thyroxine injected groups of rats in comparison to the control gastric mucosa (Fig. 3).

\section{Discussion}

The mechanism of L-thyroxin action down-regulated ghrelin secretion is still unknown. In animals, ghrelin is secreted in a pulsatile manner without strict correla-

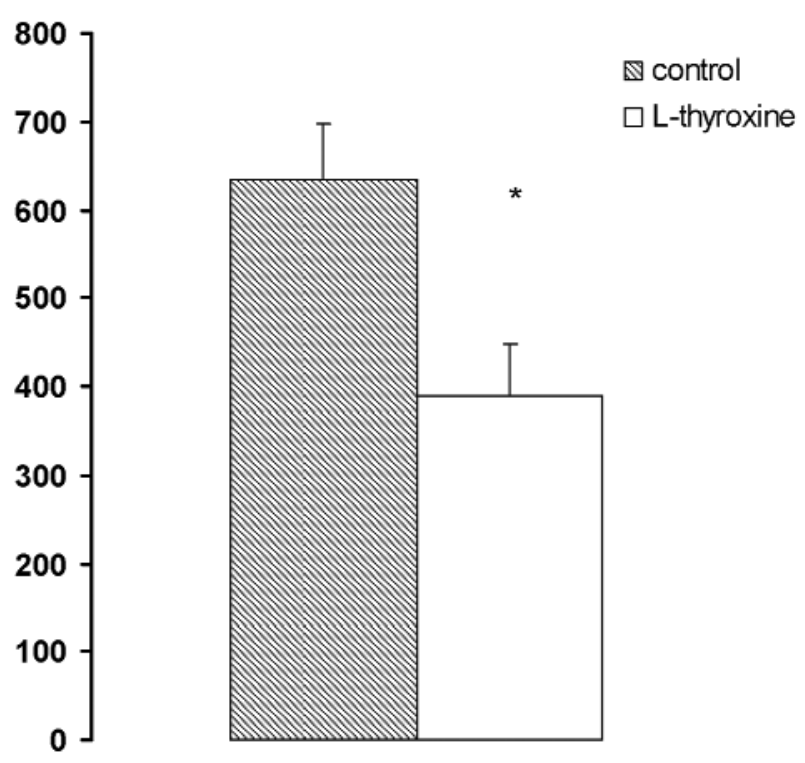

Fig. 2. The effect of L-thyroxine on plasma ghrelin concentration. Values are means \pm SD obtained from 10 rats. ${ }^{*} \mathrm{p}<0.001$ vs control (Student's test).

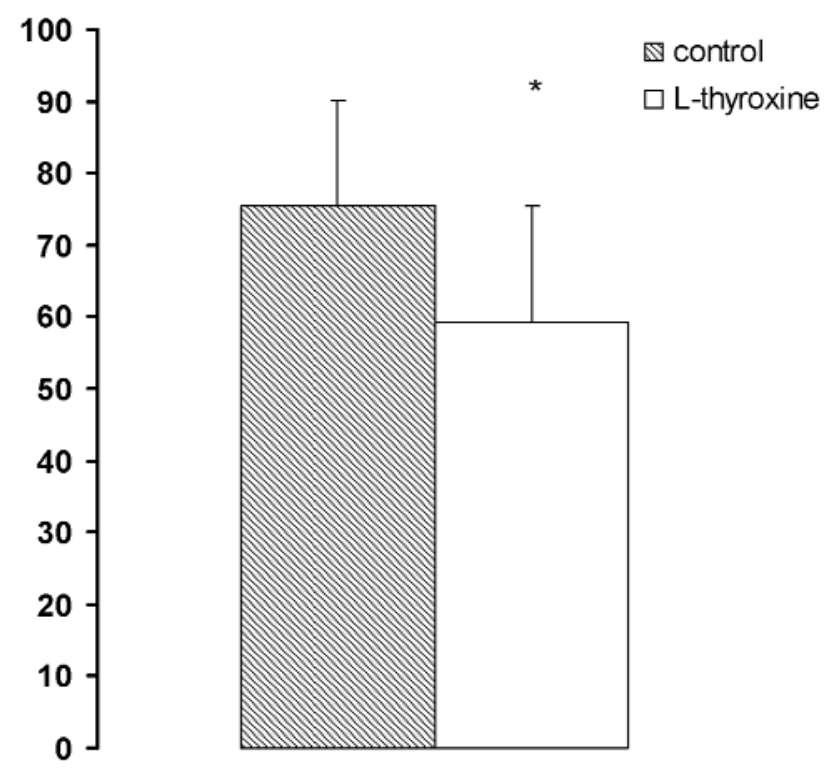

Fig. 3. Average optical density of immunohistochemical staining for ghrelin in X/A-like cells after administration of L-thyroxine. Values are means $\pm \mathrm{SD},{ }^{*} \mathrm{p}<0,001$ vs control (Mann-Whitney test).

tion with GH levels but in association with food intake episodes [16,22]. In humans, ghrelin secretion undergoes marked variations throughout the day, with peaks preceding food intake, suggesting that the latter is triggered by ghrelin discharge $[2,23]$. Circulating ghrelin levels are negatively associated with body mass index; ghrelin secretion is increased in anorexia and cachexia, reduced in obesity and normalized by recovery of ideal body weight [1]. The only exception to the negative association between body mass index and ghrelin 

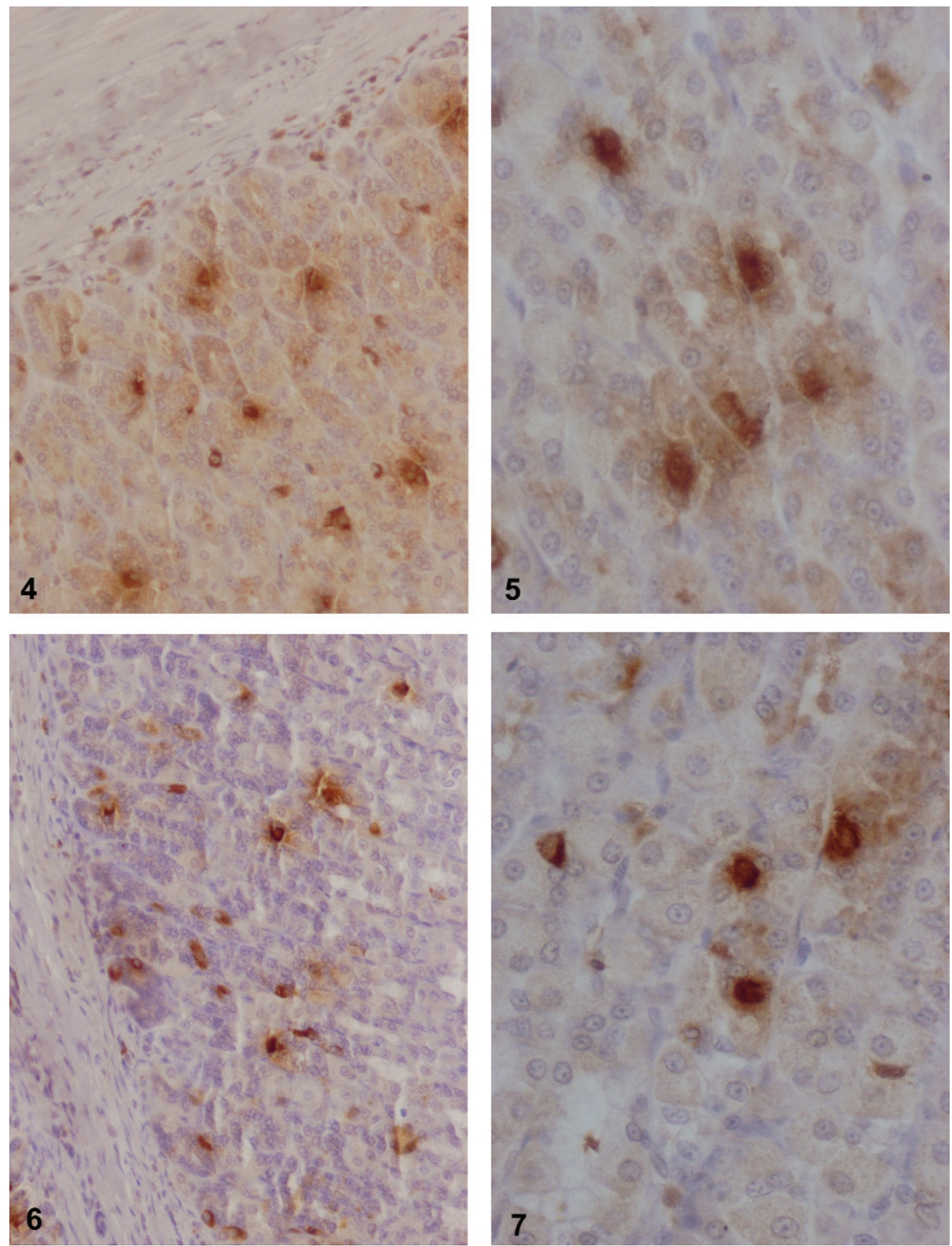

Fig. 4. Light micrograph of gastric mucosa of a control rat. Positive immunohisochemical reaction for ghrelin is observed in X/A-like cells (magnification $\times 170$ ). Fig. 5. Light micrograph of gastric mucosa of a control rat. Positive immunohisochemical reaction for ghrelin is observed in X/A-like cells (magnification $\times 340$ ). Fig. 6. Light micrograph of gastric mucosa of rat treated with L-thyroxine over 21 days. The strong immunohistochemical reaction for ghrelin is observed in most of X/A-like cells (magnification $\times 170$ ). Fig. 7. Light micrograph of gastric mucosa of rat treated with L-thyroxine over 21 days. The strong immunohistochemical reaction for ghrelin is observed in most of X/A-like cells (magnification $\times 340$ ). 
secretion is the Prader-Willi syndrome where obesity is surprisingly associated with ghrelin hypersecretion [24]. In our study we observed reduction of body weight and ghrelin plasma concentration after administration of L-thyroxine in comparison to the control group.

Ghrelin changes in response to variations in the nutritional state are opposite to those of leptin and it has been suggested that both hormones may act as signals of the metabolic balance to the central nervous system [2,7]. In our study, after L-thyroxin administration the reduction of body weight and hyperphagia accompanied by a significant decreased of ghrelin plasma levels were observed. The increase of gastric mucosal ghrelin -immunoreactivity indicated that Lthyroxin probably inhibited ghrelin secretion.

It is well known that thyroid hormone stimulates food intake in humans and rodents [25]. Hyperthyroid patients have increased appetite and energy consumption [26]. It was found that $\mathrm{T} 3$ treated rats had a marked increase hypothalamic NPY and application of BIB03304 - antagonist of Y1 receptor reduced hyperphagia in thyrotoxicosis [25]. Probably another factors induced hyperphagia in hyperthyroidism for example through the decreased plasma leptin levels, which might inhibit gastric ghrelin release [25].

The next way trying to explain the inhibition role of L-thyroxine on ghrelin secretion is hyperinsulinemia accompanied by hyperthyroidism [27]. Saad et al. [28] in 2002 reported that hyperinsulinemia reduced plasma ghrelin concentration. Ghrelin secretion is decreased by either intravenous or oral glucose load as well as during euglycaemic-hyperinsulinaemic clamp and even after insulin-induced hypoglycaemia $[29,30]$. The inhibitory influence of overexposure to insulin on ghrelin secretion is consistent with the strong negative association between ghrelin and insulin levels that had been predicted by the negative correlation between ghrelin levels and body mass index [23], however, it is still unclear whether insulin and glucose per se play a direct inhibitory role in ghrelin secretion [31].

Administration of thyroid hormone stimulate numerous of metabolic pathways and thermogenesis [27]. In humans, circulating ghrelin levels are increase by energy restriction and decrease by food intake indicating that ghrelin secretion is mostly regulated by metabolic signals [32]. Gastric ghrelin mRNA expression in rats has been increased by a high-fat diet [33], although the oral, intravenous or intragastric administration of fat has also been shown to decrease circulating ghrelin levels [34]. Similarly, oral protein administration has been reported to increase plasma ghrelin levels by some authors [32,35] or to decrease them according to others [34]. In humans, constant lipid infusion has been reported not to influence plasma ghrelin levels [30], whereas oral fat administration has been reported to decrease, although to a lesser extent than after glucose ingestion [36,37] or even to increase circulating ghrelin levels [38]. On the other hand, protein intake has been reported both to increase [36,38] and not to affect $[32,39]$ circulating ghrelin levels. Ghrelin secretion has been also inhibited by the activation of somatostatin receptors. The administration of pharmacological doses of somatostatin, its natural analogue cortistatin and a synthetic analogue such as octreotide markedly reduce circulating ghrelin levels in humans to an extent even higher than that observed after glucose or insulin administration [40,41]. Ghrelin, in turn, increases circulating somatostatin levels [42], suggesting the existence of a feedback link between these two peptides. The role of somatostatin on ghrelin secretion in hyperthyroid state is unknown.

Ghrelin secretion is also under cholinergic control [19]. The levels of ghrelin are increased and decreased by muscarinic receptors agonists and antagonists, respectively [19]. These findings agree with evidence that the elevation in ghrelin levels induced by food deprivation is prevented by subdiaphragmatic vagotomy and considerably reduced by atropine in rats [43]. Thyrotoxicosis is characterized by profound sympathovagal imbalance, caused by increased sympathetic activity in the presence of diminished vagal tone[44]. Thyroid hormones increase the density of $\beta$-adrenergic receptors and cAMP accumulation and decrease the density of $\alpha$-adrenergic receptors. Attenuated vagal tone observed during hyperthyroidism may explain decreased of plasma ghrelin level and increased of gastric mucosa immunoreactivity $[19,43]$.

\section{Conclusions}

In conclusion, our study indicated that chronic administration of L-thyroxine caused the reduction of body weight and stimulated appetite accompanied by a significant decreased of ghrelin plasma levels. The increase gastric mucosal ghrelin -immunoreactivity indicated that L-thyroxine probably inhibited ghrelin secretion. This observation showed that ghrelin is not responsible for hyperphagia in rats treated with L-thyroxine.

Acknowledgements: This study was supported by AMB grant no 3-40839.

\section{References}

[1] Ariyasu, H, Takaya K, Tagami T, Ogawa Y, Hosoda K, Akamizu T, Suda M, Koh T, Natsui K, Toyooka S, Shirakami G, Usui T, Shimatsu A, Doi K, Hosoda H, Kojima M, Kangawa K, Nakao K. Stomach is a major source of circulating ghrelin, and feeding state determines plasma ghrelin-like immunoreactivity levels in humans. J Clin Endocrinol Metab. 2001;86:4753-4758.

[2] Inui A. Ghrelin: an orexigenic and somatotrophic signal from 
the stomach. Nature Reviews. Neuroscience. 2001;2:551-560.

[ 3] Kalra SP, Kalra PS. Neuropeptide Y: a physiological orexigen modulated by the feedback action of ghrelin and leptin. Endocrine. 2003;22:49-56.

[ 4] Kojima M, Hosoda H, Date Y, Nakazato M, Matsuo H, Kangawa $\mathrm{K}$. Ghrelin is a growth-hormone-releasing acylated peptide from stomach. Nature. 1999;402:656-660.

[ 5] Cummings DE, Frayo RS, Marmonier C, Aubert R, Chapelot D. Plasma ghrelin levels and hunger scores in humans initiating meals voluntarily without time- and foodrelated cues. Am J Physiol Endocrinol Metab. 2004;287:297-304.

[ 6] Kojima M, Hosoda H, Matsuo H, Kangawa K. Ghrelin: discovery of the natural endogenous ligand for the growth hormone secretagogue receptor. Trends in Endocrinology and Metabolism. 2001;12:118-122.

[7] Horvath TL, Diano S, Sotonyi P, Heiman M, Tschop M. Minireview: ghrelin and the regulation of energy balance $-\mathrm{a}$ hypothalamic perspective. Endocrinology. 2001;142:41634169.

[ 8] Tschop M, Smiley DL, Heiman ML. Ghrelin induces adiposity in rodents. Nature. 2000;407:908-913.

[ 9] van der Lely AJ, Tschop M, Heiman ML, Ghigo E. Biological, physiological, pathophysiological, and pharmacological aspects of ghrelin. Endocrine Reviews. 2004;25:426-457.

[10] Takachi K, Doki Y, Ishikawa O, Miyashiro I, Sasaki Y, Ohigashi $\mathrm{H}$, Murata $\mathrm{K}$, Nakajima $\mathrm{H}$, Hosoda H, Kangawa $\mathrm{K}$, Sasakuma F, Imaoka S. Postoperative ghrelin levels and delayed recovery from body weight loss after distal or total gastrectomy. J Surg Res. 2006;130:1-7.

[11] Date Y, Kojima M, Hosoda H, Sawaguchi A, Mondal MS,Suganuma T, Matsukura S, Kangawa K, Nakazato M. Ghrelin, a novel growth hormone-releasing acylated peptide, is synthesized in a distinct endocrine cell type in the gastrointestinal tracts of rats and humans. Endocrinology. 2000;141:4255-4261.

[12] Gnanapavan S, Kola B, Bustin SA, Morris DG, McGee P, Fairclough P, Bhattacharya S, Carpenter R, Grossman AB, Korbonits M. The tissue distribution of the mRNA of ghrelin and subtypes of its receptor, GHS-R, in humans. J Clin Endocrinol Metab. 2002;87: 2988.

[13] Korbonits M, Bustin SA, Kojima M, Jordan S, Adams EF, Lowe DG, Kangawa K, Grossman AB. The expression of the growth hormone secretagogue receptor ligand ghrelin in normal and abnormal human pituitary and other neuroendocrine tumors. J Clin Endocrinol Metab. 2001;86:881-887.

[14] Lawrence CB, Snape AC, Baudoin FM, Luckman SM. Acute central ghrelin and GH secretagogues induce feeding and activate brain appetite centers. Endocrinology. 2002; 143:155-162.

[15] Shintani M, Ogawa Y, Ebihara K, Izawa-Abe M, Miyanaga F, Takaya K, Hayashi T, Inoue G, Hosoda K, Kojima M,Kangawa K, Nakao K. Ghrelin, an endogenous growth hormone secretagogue, is a novel orexigenic peptide that antagonizes leptin action through the activation of hypothalamic neuropeptide Y/Y1 receptor pathway. Diabetes. 2001;50:227-232.

[16] Bagnasco M, Kalra PS Kalra SP. Ghrelin and leptin pulse discharge in fed and fasted rats. Endocrinology. 2002;143:726729.

[17] Bagnasco M, Tulipano G, Melis MR, Argiolas A, Cocchi D Muller EE. Endogenous ghrelin is an orexigenic peptide acting in the arcuate nucleus in response to fasting. Regul Pept. 2003;111:161-167.

[18] Gualillo O, Lago F, Gomez-Reino J, Casanueva FF, Dieguez C. Ghrelin, a widespread hormone: insights into molecular and cellular regulation of its expression and mechanism of action. FEBS Letters. 2003;552:105-109.

[19] Broglio F, Van Gottero CKP, Prodam F, Destefanis S, Benso A, Gauna C, Hofland L, Arvat E, van der Lely AJ Ghigo E.
Acetylcholine regulates ghrelin secretion in humans. $J$ Clin Endocrinol Metab. 2004;89:2429-2433.

[20] Zbucki RL, Winnicka MM, Sawicki B, Szynaka B, Andrzejewska A, Puchalski Z. Alteration of parafollicular (C) cells activity in the experimental model of hypothyroidism in rats. Folia Histochem Cytobiol. 2007;45:115-21.

[21] Postek A, Andronowska T, Doboszynska T, Nieweglowski H, Jankowska K. VEGF, VEGFR-1 and VEGFR-2 immunoreactivity in the porcine arteries of vascular subovarian plexus (VSP) during the estrous cycle. Folia Histochem Cytobiol. 2006;44:17-23.

[22] Wren AM, Seal LJ, Cohen MA., Brynes AE, Frost GS, Murphy KG, Dhillo WS, Ghatei MA, Bloom SR. Ghrelin enhances appetite and increases food intake in humans. J Clin Endocrinol Metab. 2001;86:5992.

[23] Schaller G, Schmidt A, Pleiner J, Woloszczuk W, Wolzt M, Luger A. Plasma ghrelin concentrations are not regulated by glucose or insulin: a double-blind, placebo-controlled crossover clamp study. Diabetes. 2003;52:16-20.

[24] Haqq AM, Farooqi IS, O'Rahilly S, Stadler DD, Rosenfeld RG, Pratt KL, LaFranchi SH, Purnell JQ. Serum ghrelin levels are inversely correlated with body mass index, age, and insulin concentrations in normal children and are markedly increased in Prader-Willi syndrome. J Clin Endocrinol Metab. 2003;88:174-178.

[25] Ishii S, Kamegai J, Tamura H, Shimizu T, Sugihara H, Oikawa S. Hypothalamic neuropeptide Y/Y1 receptor pathway activated by a reduction in circulating leptin, but not by an increase in circulating ghrelin, contributes to hyperphagia associated with triiodothyronineinduced thyrotoxicosis. Neuroendocrinology. 2003;78:321-30.

[26] Pétervári E, Balaskó M, Jech-Mihálffy A, Székely M. Hyperphagia of hyperthyroidism: is neuropeptide Y involved? Regul Pept. 2005;131:103-110.

[27] Al-Shoumer KA, Vasanthy BA, Al-Zaid MM. Effects of treatment of hyperthyroidism on glucose homeostasis, insulin secretion, and markers of bone turnover. Endocr Pract. 2006;12:121-130.

[28] Saad MF, Bernaba B, Hwu CM, Jinagouda S, Fahmi S, Kogosov E, Boyadjian R. Insulin regulates plasma ghrelin concentration. J Clin Endocrinol Metab. 2002;87:3997-4000.

[29] Lucidi P, Murdolo G, Di Loreto C, De Cicco A, Parlanti N,Fanelli C, Santeusanio F, Bolli GB, De Feo P. Ghrelin is not necessary for adequate hormonal counterregulation of insulin-induced hypoglycemia. Diabetes. 2002;51:29112914.

[30] Mohlig M, Spranger J, Otto B, Ristow M, Tschop M, Pfeiffer AF. Euglycemic hyperinsulinemia, but not lipid infusion, decreases circulating ghrelin levels in humans. $J$ Endocrinol Invest. 2002;25:36-38.

[31] Caixas A, Bashore C, Nash W, Pi-Sunyer F, Laferrere B. Insulin, unlike food intake, does not suppress ghrelin in human subjects. J Clin Endocrinol Metab. 2002;87:1902.

[32] Groschl M, Knerr I, Topf HG, Schmid P, Rascher W, Rauh M. Endocrine responses to the oral ingestion of a physiological dose of essential amino acids in humans. $J$ Endocrinol. 2003; 179:237-244

[33] Asakawa A, Inui A, Kaga T, Katsuura G, Fujimiya M, Fujino MA Kasuga M. Antagonism of ghrelin receptor reduces food intake and body weight gain in mice. Gut. 2003;52:947-952.

[34] Gomez G, Englander EW, Greeley GH. Nutrient inhibition of ghrelin secretion in the fasted rat. Regul Pept. 2004;117:3336.

[35] Lee HM, Wang G, Englander EW, Kojima M, Greeley GH. Ghrelin, a new gastrointestinal endocrine peptide that stimulates insulin secretion: enteric distribution, ontogeny, influence of endocrine, and dietary manipulations. Endocrinology. 2002;143:185-190. 
[36] Erdmann J, Lippl F, Schusdziarra V. Differential effect of protein and fat on plasma ghrelin levels in man. Regul Pept 2003;116:101-107.

[37] Monteleone P, Bencivenga R, Longobardi N, Serritella C, Maj M. Differential responses of circulating ghrelin to highfat or high-carbohydrate meal in healthy women. $J$ Clin Endocrinol Metab. 2003;88: 5510 -5514.

[38] Erdmann J, Topsch R, Lippl F, Gussmann P, Schusdziarra V. Postprandial response of plasma ghrelin levels to various test meals in relation to food intake, plasma insulin, and glucose. $J$ Clin Endocrinol Metab. 2004;89:3048-54.

[39] Knerr I, Groschl M, Rascher W, Rauh M. Endocrine effects of food intake: insulin, ghrelin, and leptin responses to a single bolus of essential amino acids in humans. Annals of Nutrition and Metabolism. 2003;47:312-318.

[40] Broglio F, Koetsveld PP, Benso A, Gottero C, Prodam F, Papotti M, Muccioli G, Gauna C, Hofland L, Deghenghi R, Arvat E, van der Lely AJ Ghigo E. Ghrelin secretion is inhibited by either somatostatin or cortistatin in humans. $J$ Clin Endocrinol Metab. 2002;87:4829-4832.
[41] Norrelund H, Hansen TK, Orskov H, Hosoda H, Kojima M, Kangawa K, Weeke J, Moller N, Christiansen JS, Jorgensen JO. Ghrelin immunoreactivity in human plasma is suppressed by somatostatin. Clinical Endocrinology (Oxford). 2002;57: 539-546.

[42] Arosio M, Ronchi CL, Gebbia C, Cappiello V, Beck-Peccoz P Peracchi M. Stimulatory effects of ghrelin on circulating somatostatin and pancreatic polypeptide levels. J Clin Endocrinol Metab. 2003;88:701-704.

[43] Williams DL, Grill HJ, Cummings DE, Kaplan JM. Vagotomy dissociates short- and long-term controls of circulating ghrelin. Endocrinology. 2003;144:5184-5187.

[44] Burggraaf J, Tulen JH, Lalezari S, Schoemaker RC, De Meyer PH, Meinders AE, Cohen AF, Pijl H. Sympathovagal imbalance in hyperthyroidism. Am J Physiol Endocrinol Metab. 2001;281:190-195.

Submitted: 17 January, 2008 Accepted after reviews: 19 July, 2008 